DOI: $10.26693 / j m b s 06.01 .177$

UDC 579.262.085:579.861.2:579.862. 1:579.841.11:579.842.16:616.2-053.2

Isaieva H. O.', Mishyna M. M.', Mozgova Y. A. ${ }^{1}$,

Gonchar M. O.', Logvinova O. L.' ${ }^{1}$ Basiuk M. A. ${ }^{2}$

\title{
ABILITY OF MICROORGANISMS, CAUSING RESPIRATORY INFECTIONS IN CHILDREN, TO FORM BIOFILMS in vitro
}

\author{
${ }^{1}$ Kharkiv National Medical University, Ukraine \\ ${ }^{2}$ Kharkiv Regional Children's Clinical Hospital, Ukraine
}

anna1989isaeva@ukr.net

The purpose of the study was to detect ability to form biofilms by microorganisms that cause respiratory tract infections.

Materials and methods. The study involved 97 strains of microorganisms. Microorganisms were isolated from children with respiratory tract infections. All strains, isolated from patients, were able to form biofilms. There were 44 strains of $S$. aureus (from patients with pneumonia - 13 strains, from patients with other respiratory diseases -31 ), 34 strains of $S$. pneumoniae (pneumonia - 27 strains, other respiratory diseases -7 ), 13 strains of $K$. pneumoniae (pneumonia -6 strains, other respiratory diseases -7 ), 6 strains of $P$. aeruginosa (pneumonia -5 strains, other respiratory diseases -1 ). Children were treated at the pulmonary department and intensive care unit in Kharkiv Regional Children's Clinical Hospital.

Results and discussion. The optical density of primary biofilms formed by Gram-positive microorganisms was $1.33 \pm 0.24$ Units of $O D$, and their secondary biofilms was $0.32 \pm 0.10$ Units of OD. In patients with pneumonia optical density of primary biofilms of Gram-positive microorganisms was $1.48 \pm 0.21$ Units of OD and of secondary biofilms was $0.30 \pm 0.08$ Units of OD. Optical density of primary biofilms of Gram-positive microorganisms in patients with other respiratory infections was $1.18 \pm 0.15$ Units of $O D$, of secondary biofilms was $0.35 \pm 0.12$ Units of OD. The optical density of primary biofilms formed by Gram-negative microorganisms was $2.01 \pm 1.03$ Units of OD, optical density of secondary biofilms was $1.06 \pm 0.42$ Units of OD. In patients with pneumonia optical density of primary biofilms of Gram-negative microorganisms was $2.57 \pm 0.87$ Units of $\mathrm{OD}$, of secondary biofilms was $1.21 \pm 0.50$ Units of OD. Optical density of primary biofilms of Gram-negative microorganisms in patients with other respiratory infections was $1.24 \pm 0.66$ Units of $\mathrm{OD}$, of secondary biofilms was $0.84 \pm 0.11$ Units of OD.

Conclusion. Gram-negative microorganisms in general formed more massive biofilms compared with Gram-positive microorganisms. Among all microorganisms $P$. aeruginosa formed the thickest primary and secondary biofilms. Strains of $P$. aeruginosa isolated from patients with pneumonia formed the thickest primary and secondary biofilms. Strains of $S$. aureus isolated from patients with other respiratory infections formed most massive primary biofilms, strains of $K$. pneumoniae formed the hardest secondary biofilms in this group.

Keywords: biofilms, children, respiratory diseases, S. aureus, S. pneumoniae, K. pneumoniae, $P$. aeruginosa.

Research relation to the programs, plans, and department themes. The research was carried out within the framework of the initiative topic "Experimental discourse of application of a complex of antibacterial agents on the basis of detection of microbiological features of microorganisms that cause purulent-inlammatory diseases", the State Registration Number is $0120 \mathrm{U} 102569$.

Inroduction. A biofilm is defined as a sessile microbial community in which cells are attached to a surface or to other cells and embedded in a protective extracellular polymeric matrix [1-4]. The EPS matrix allows the microbes to function synergistically as a community by maintaining close contact via intercellular communication pathways and sharing group resources [5-7]. The formation and dispersal of biofilms is regulated by several mechanisms, including quorum sensing (QS), bis-(3'-5') cyclic diguanosine monophosphate (c-di-GMP) signaling, and regulation of small RNAs $[7,8]$. The growth in a biofilm plays an important role during infection by providing a defense against several clearance mechanisms. The biofilm matrix can impede the access of certain types of immune defenses, such as macrophages, which display incomplete penetration into the biofilm matrix and "frustrated phagocytosis" [4, 9].

Biofilms growth on host tissues and medical devices act as a key mechanism of virulence for opportunistic pathogens such as Pseudomonas aeruginosa, staphylococcal species, and the fungi [10]. The ability of $P$. aeruginosa to form biofilms is a critical factor that allows it to cause severe and recalcitrant infections associated with significant morbidity and mortality [7, 11]. Biofilms provide $P$. aeruginosa an enormous advantage by promoting survival on artificial materials, 
evasion from the immune system, and tolerance to antimicrobial therapy [7, 11-14].

The purpose of the study was to detect ability of microorganisms that cause respiratory tract infections, to form biofilms.

Materials and methods. For detection of biofilms formation 97 strains of $S$. aureus, S. pneumoniae, $K$. pneumoniae, $P$. aeruginosa were isolated from children with respiratory diseases, namely 44 strains of $S$. aureus (pneumonia - 13 strains, other respiratory diseases -31 ), 34 strains of $S$. pneumoniae (pneumonia -27 strains, other respiratory diseases -7 ), 13 strains of $K$. pneumoniae (pneumonia -6 strains, other respiratory diseases -7 ), 6 strains of $P$. aeruginosa (pneumonia - 5 strains, other respiratory diseases - 1). Microorganisms were isolated and identified by routine microbiological methods [15].

Polystyrene flat-bottom 96-well plates were used for detection of biofilms formation. Night cultures of isolated microorganisms were diluted by fresh nutrient medium 1:100. Obtained suspensions in sterile conditions were inoculated in the dose of $150 \mu \mathrm{L}$ into the wells of the plates. Plates were incubated at $28^{\circ} \mathrm{C}$ for 24 hours under moist conditions. Optical density of the obtained cells was detected with the aid of Multiskan photometer with wave length of $540 \mathrm{~nm}$. After that, content of the wells was carefully removed and into the wells were added $150 \mu \mathrm{L}$ of distilled water and $15 \mu \mathrm{L} 1 \%$ alcohol solution of crystal violet. Wells that were filled with dye were incubated at room temperature for 45 minutes. Then the dye was carefully aspirated and wells were rinsed three times with distilled water with the aid of multi channel dropper. Into the washed wells $250 \mu \mathrm{L}$ of ethyl alcohol was added and left for 45 minutes at room temperature. Intensity of attaining was done with photometer with wave length of $540 \mathrm{~nm}$ [16].

All examined patients and their parents signed an informative consent, the study was conducted in accordance with the Declaration of Helsinki of the World Medical Association of Bioethics, standard provisions on ethics of the Ministry of Health of Ukraine №66 of February 12, 2006.

The Wilcoxon Matched Pairs Test - nonparametric method was used due to small amount of experiments. The differences were evaluated using the chisquared test. A $P$ value less than 0.05 was considered statistically significant. Means \pm standard deviation of at least three independent replicates are depicted. Significance was determined using the Kruskal-Wallis ANOVA by Ranks.

Results and discussion. Optical density (OD) of primary biofilms that formed microorganisms, isolated from patients was $1.46 \pm 0.56$ Units of $O D, O D$ of secondary biofilms was $0.47 \pm 0.36$ Units of OD. OD of primary biofilms formed by microorganisms, isolated from patients with pneumoniae was $1.71 \pm 0.63$ Units of OD, of secondary biofilms was $0.50 \pm 0.45$ Units of OD. OD of primary biofilms formed by microorganisms, isolated from patients with other respiratory infections was $1.19 \pm 0.29$ Units of $O D$, of secondary biofilms was $0.43 \pm 0.22$ Units of OD.

OD of primary biofilms formed by Gram-positive microorganisms was $1.33 \pm 0.24$ Units of $O D$, of secondary biofilms was $0.32 \pm 0.10$ Units of $O D$. OD of primary biofilms was thicker than $\mathrm{OD}$ of secondary biofilms, $Z=7.67, p<0.05$. OD of primary biofilms formed by Gram-positive microorganisms in patients with pneumonia was $1.48 \pm 0.21$ Units of $\mathrm{OD}, \mathrm{OD}$ of secondary biofilms was $0.30 \pm 0.08$ Units of OD. OD of primary biofilms was more massive than $O D$ of secondary biofilms, $Z=5.51, p<0.05$. OD of primary biofilms formed by Gram-positive microorganisms isolated from patients with other respiratory infections was $1.18 \pm 0.15$ Units of $O D$, of secondary biofilms was $0.35 \pm 0.12$ Units of OD. OD of primary biofilms was harder than OD of secondary biofilms, $Z=5.37$, $p<0.05$.

Gram-negative microorganisms formed primary biofilms with OD $2.01 \pm 1.03$ Units of $O D, O D$ of secondary biofilms was $1.06 \pm 0.42$ Units of $O D$, $p=0,000132$. OD of primary biofilms formed by Gram-negative microorganisms in patients with pneumonia was $2.57 \pm 0.87$ Units of $O D$, of secondary biofilms was $1.21 \pm 0.50$ Units of OD, $p=0.003346$. OD of primary biofilms formed by Gram-negative microorganisms in patients with other respiratory infections was $1.24 \pm 0.66$ Units of $\mathrm{OD}, \mathrm{OD}$ of secondary biofilms was $0.84 \pm 0.11$ Units of $O D, p=0.011719$.

OD of primary biofilms formed by $S$. aureus strains was $1.29 \pm 0.17$ Units of $O D, O D$ of secondary biofilms was $0.30 \pm 0.08$ Units of OD. Primary biofilms were thicker than secondary, $Z=5.776745, p<0.05$. OD of primary biofilms formed by $S$. aureus strains in patients with pneumonia was $1.46 \pm 0.12$ Units of OD, of secondary biofilms was $0.26 \pm 0.04$ Units of OD. Primary biofilms were more massive than secondary, $p=$ 0.001474 . OD of primary biofilms formed by $S$. aureus strains in patients with other respiratory infections was $1.22 \pm 0.13$ Units of $O D, O D$ of secondary biofilms was $0.31 \pm 0.08$ Units of OD. Primary biofilms were harder than secondary, $p=0.000001$.

OD of primary biofilms formed by $S$. pneumoniae strains was $1.38 \pm 0.30$ Units of $O D, O D$ of secondary biofilms was $0.35 \pm 0.12$ Units of OD. Primary biofilms were thicker than secondary, $Z=5.086213, p<0.05$. OD of primary biofilms formed by $S$. pneumoniae strains in patients with pneumonia was $1.49 \pm 0.25$ Units of OD, OD of secondary biofilms was $0.32 \pm$ 0.08 Units of OD. Primary biofilms were more massive than secondary, $p=0.000006$. OD of primary biofilms formed by $S$. pneumoniae strains in patients 
with other respiratory infections was $1.00 \pm 0.09$ Units of OD, OD of secondary biofilms was $0.49 \pm 0.15$ Units of OD. Primary biofilms were harder than secondary, $p=0,017961$.

OD of $K$. pneumoniae primary biofilms was $1.49 \pm 0.81$ Units of $O D, O D$ of secondary biofilms was $0.92 \pm 0.24$ Units of OD. Primary biofilms were thicker than secondary, $p=0.001474$. OD of $K$. pneumoniae primary biofilms in patients with pneumonia was 2.06 \pm 0.91 Units of OD, of secondary biofilms was $0.98 \pm 0.34$ Units of OD. Primary biofilms were more massive than secondary, $p=0.027709$. OD of $K$. pneumoniae primary biofilms in patients with other respiratory infections was $1.00 \pm 0.05$ Units of $O D$, of secondary biofilms was $0.87 \pm 0.10$ Units of OD. Primary biofilms were harder than secondary, $p=0.017961$.

OD of primary biofilms formed by $P$. aeruginosa strains was $3.13 \pm 0.15$ Units of $O D, O D$ of secondary biofilms was $1.36 \pm 0.59$ Units of OD. Primary biofilms were thicker than secondary, $p=0.027709$. OD of primary biofilms formed by $P$. aeruginosa strains in patients with pneumonia was $3.18 \pm 0.09$ Units of OD, of secondary biofilms was $1.50 \pm 0.55$ Units of OD. Primary biofilms were more massive than secondary, $p=$ 0.043115 .

Comparing of primary biofilms OD using Kruskal-Wallis test among all 4 microorganisms revealed that the highest index was detected in $P$. aeruginosa, the lowest was found in S. aureus: $H(3.97)=20.08$, $p=0.0002$ (Fig. 1).

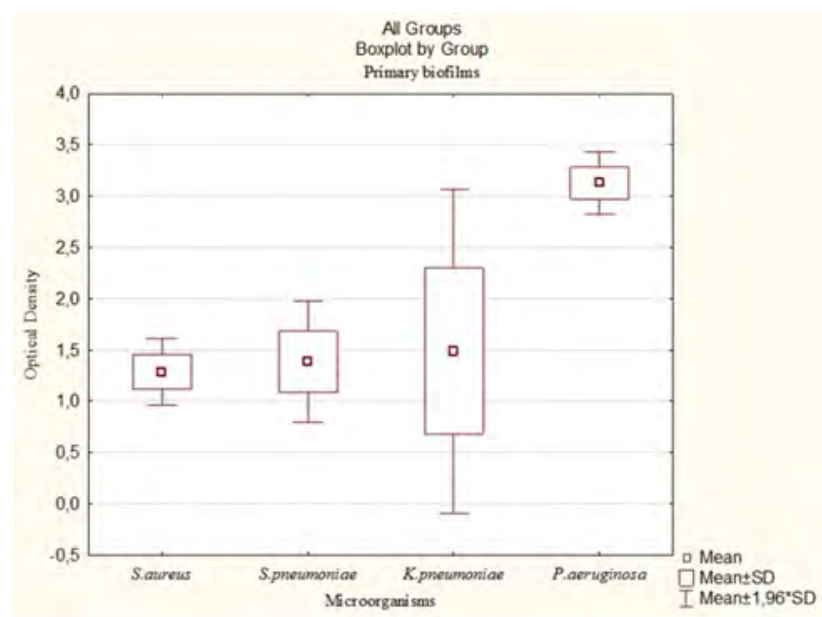

Fig. 1. Comparison of primary biofilms OD formed by microorganisms, isolated from all patients

Comparing of secondary biofilms OD among all 4 microorganisms revealed that the highest index was detected in $P$. aeruginosa, the lowest was found in S. aureus: $\mathrm{H}(3.97)=48.51, p<0.05$ (Fig. 2).

Comparison of the primary biofilms OD among all 4 microorganisms in patients with pneumonia revealed the highest index in $P$. aeruginosa with the lowest in $S$. aureus: $H(3,51)=13.29, p=0.0041$ (Fig. 3).

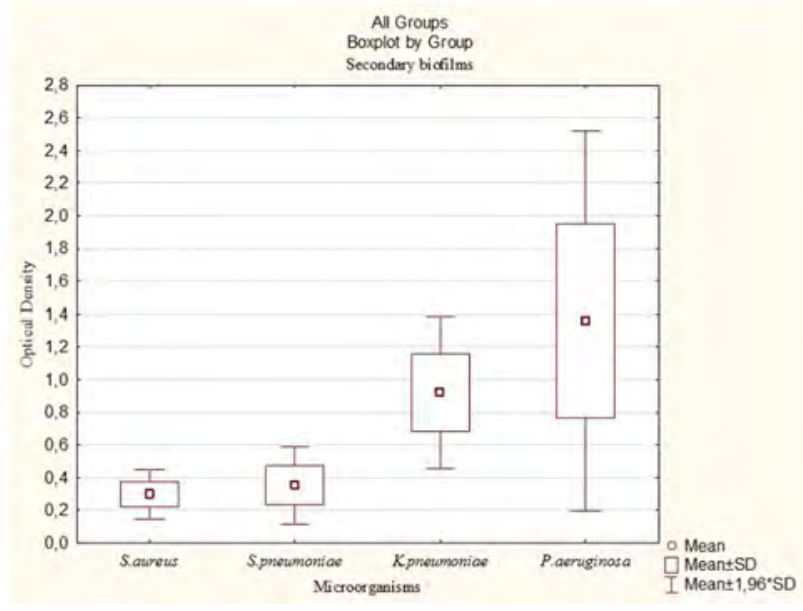

Fig. 2. Comparison of secondary biofilms OD formed by microorganisms, isolated from all patients

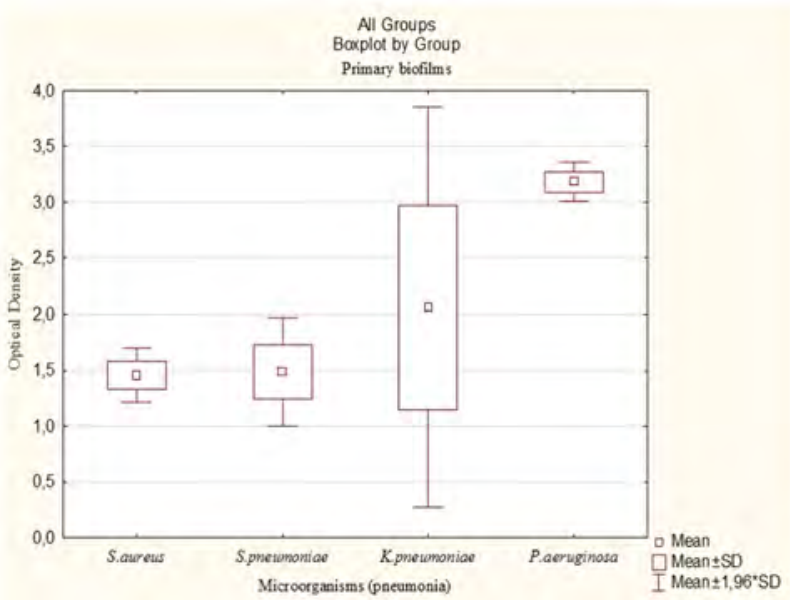

Fig. 3. Comparison of primary biofilms OD formed by microorganisms, isolated from patients with pneumonia

Comparing OD of secondary biofilms among all 4 microorganisms in patients with pneumonia revealed the highest index in $P$. aeruginosa with the lowest in $S$. aureus: $\mathrm{H}(3.51)=27.34, p<0.05$ (Fig. 4).

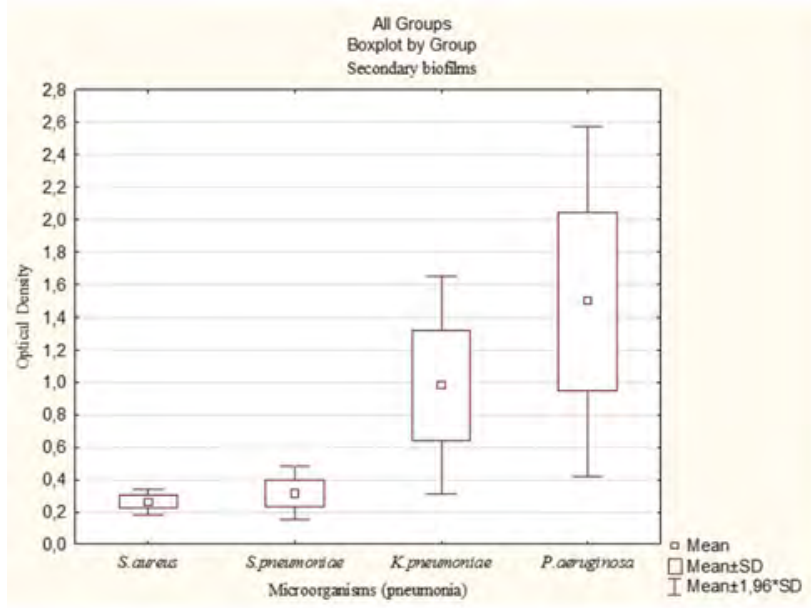

Fig. 4. Comparison of secondary biofilms OD formed by microorganisms, isolated from patients with pneumonia 
Comparison of primary biofilms OD among 3 microorganisms in patients with other respiratory diseases revealed the highest index in $S$. aureus with the lowest in $K$. pneumoniae: $H(2.45)=24.53$, $p<0.05$ (Fig. 5).

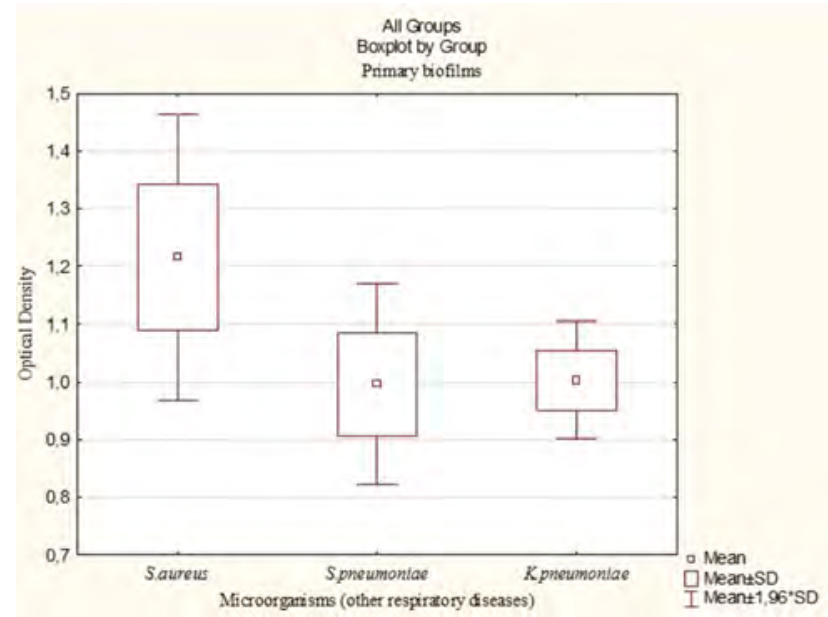

Fig. 5. Comparison of primary biofilms $O D$ formed by microorganisms, isolated from patients with other respiratory diseases

Comparing OD of secondary biofilms among 3 microorganisms in patients with other respiratory diseases revealed the highest index in $K$. pneumoniae with the lowest in S. aureus: $\mathrm{H}(2.45)=22.69, p<0.05$ (Fig. 6).

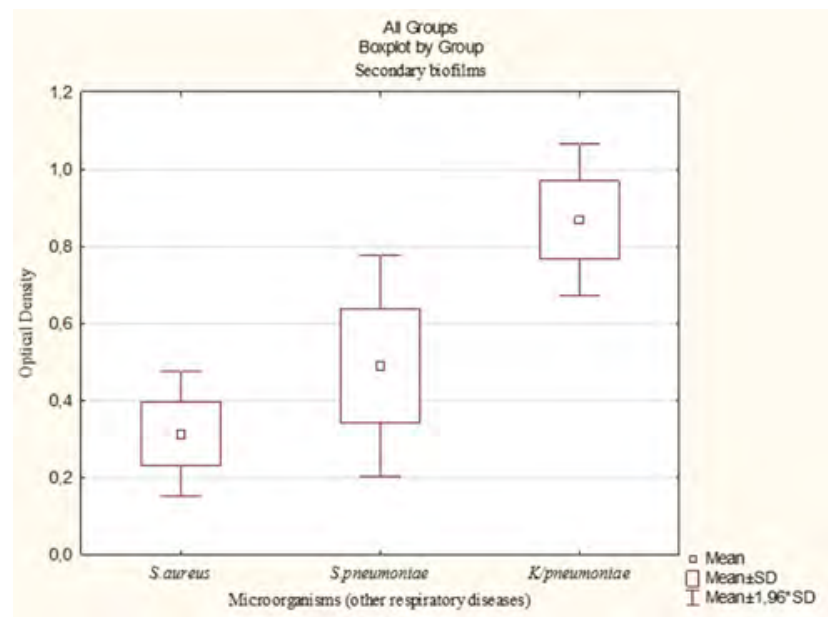

Fig. 6. Comparison of secondary biofilms $O D$ formed by microorganisms, isolated from patients with other respiratory diseases

All isolates were able to form biofilms. Both Gram-positive and Gram-negative microorganisms formed primary biofilms that were thicker than secondary biofilms.

OD of primary and secondary biofilms of $P$. aeruginosa strains in patients with pneumonia was the highest among all microorganisms. OD of primary and secondary biofilms of $S$. aureus strains in patients with pneumonia was the lowest among all microorganisms.
On other hand, in patients with other respiratory diseases the highest OD of primary biofilms was detected in the strains of $S$. aureus, the lowest - in strains of $K$. pneumoniae. OD of secondary biofilms of $K$. pneumoniae strains in patients with other respiratory diseases was the highest among 3 microorganisms ( $S$. aureus, $S$. pneumoniae, K. pneumoniae). OD of secondary biofilms of $S$. aureus strains in patients with other respiratory diseases was the lowest among 3 microorganisms ( $S$. aureus, $S$. pneumoniae, K. pneumoniae).

S. aureus, like all bacteria, expresses myriad virulence factors upon entering the host environment that aid it in adhering to host tissues, proliferating inside the host, and evading the immune system. In recent years, $S$. aureus has become an emerging cause of community acquired pneumonia. Pneumonia caused by $S$. aureus is a significant cause of morbidity and mortality and can induce severe lung destruction [17].

There are several steps in the biofilm's formation: initial contact and attachment to the surface; microcolony formation; maturation and formation of the architecture of the biofilm; detachment and dispersal of the biofilms. One of the most important steps in biofilms formation is attachment. $P$. aeruginosa has several mechanisms that help this microorganism in this stage. The type $\mathrm{V}$ secretion system (autotransport system) plays role in biofilms formation and cellular adherence. The soluble lectins, LecA and LecB, are present in the outer membrane of $P$. aeruginosa that may participate in adhesion and play a major role in the severity of $P$. aeruginosa - induce lung bacterial load, influencing its survival and biofilms formation [18].

In the respiratory tract present barriers which prevent the establishment of infection, such as the presence of mucus, opsonins, innate immune cells, and additional factors. Activation of $P$. aeruginosa QS alters innate and adaptive responses and, along with the associated cytotoxic effects of the virulence factors, allows for the establishment of a severe lower respiratory tract infection, especially pneumonia. [19].

The severity of $P$.aeruginosa is due to its secretion of exoenzymes. Also, $P$. aeruginosa has single polar flagellum and multiple cell surface pili (type IV) that responsible for adherence to cell membranes and other surfaces [18]. Taking everything into account it can be explained why strains of $P$. aeruginosa formed the thickest primary biofilms.

Secondary biofilms in all cases were thinner than primary among and Gram-positive and Gram-negative microorganisms. It can be defined the fact that QS can inhibit production of flagella and other adhesins on the stage of the biofilm's formation, because they are thought to be strong immunogens and they stimulate formation of interleukins [20-23]. 


\section{Conclusion}

In the present study microorganisms causing respiratory tract infections in children were able to form more massive primary biofilms that can play a more significant role in the severity of pneumonia compared with other respiratory infections. OD of primary biofilms formed by microorganisms causing pneumonia was $1.71 \pm 0.63$ Units of $O D, O D$ of primary biofilms formed by microorganisms causing other respiratory infections was $1.19 \pm 0.29$ Units of OD.

Comparing OD of primary $(H(3,97)=20.08$, $p=0.0002))$ and secondary $(\mathrm{H}(3,97)=48.51, p<0.05))$ biofilms formed by $S$. aureus, $S$. pneumoniae, K. pneumoniae, $P$. aeruginosa using Kruskal-Wallis test revealed the highest index in $P$. aeruginosa and the lowest in $S$. aureus.

$P$. aeruginosa isolated from patients with pneumonia formed the thickest primary and secondary biofilms.

$S$. aureus formed most massive primary biofilms in patients with other respiratory diseases, $K$. pneumoniae formed the hardest secondary biofilms in this category of patients.

Prospects for further research. It is planned to detect susceptibility of $S$. aureus, $S$. pneumoniae, $K$. pneumoniae, $P$. aeruginosa in their biofilms form to the action of the antibacterial drugs in vitro.

\section{References}

1. Parsek MR, Singh PK. Bacterial biofilms: an emerging link to disease pathogenesis. Annual Review of Microbiology. 2003; 57: 677-701. doi: 10.1146/annurev.micro.57.030502.090720

2. Archer NK, Mazaitis MJ, Costerton JW, Leid J G, Powers ME, Shirtliff ME. Staphylococcus aureus biofilms: properties, regulation, and roles in human disease. Virulence. 2011; 2(5): 445-459. doi: 10.4161/viru.2.5.17724

3. Kiedrowski MR, Horswill AR. New approaches for treating staphylococcal biofilm infections. Annals of New York Academy of Science. 2011; 1241: 104-121. doi: 10.1111/j.1749-6632.2011.06281.x

4. Lister JL, Horswill AR. Staphylococcus aureus biofilms: recent developments in biofilm dispersal. Frontiers in Cellular and Infection Microbiology. 2014; 4(178). doi: 10.3389/fcimb.2014.00178

5. Flemming HC, Wingender J. The biofilm matrix. Nature Reviews Microbiology. 2010; 8: 623-633. doi: 10.1038/ nrmicro2415

6. Gunn JS, Bakaletz LO, Wozniak DJ. What's on the outside matters: the role of the extracellular polymeric substance of gram-negative biofilms in evading host immunity and as a target for therapeutic intervention. Journal of Biological Chemistry. 2016; 291: 12538-12546. doi: 10.1074/jbc.R115.707547

7. Maurice NM, Bedi B, Sadikot RT. Pseudomonas aeruginosa Biofilms: Host Response and Clinical Implications in Lung Infections, American Journal of Respiratory Cell and Molecular Biology. 2018; 58(4): 428-439. doi: 10.1165/ rcmb.2017-0321TR

8. Fazli M, Almblad H, Rybtke ML, Givskov M, Eberl L, Tolker-Nielsen T. Regulation of biofilm formation in Pseudomonas and Burkholderia species. Environmental Microbiology.2014; 16(7): 1961-1981. doi: 10.1111/1462-2920.12448

9. Scherr TD, Heim CE, Morrison JM, Kielian T. Hiding in plain sight: interplay between staphylococcal biofilms and host immunity. Frontiers in Immunology. 2014; 5(37). doi: 10.3389/fimmu.2014.00037

10. Boisvert AA, Cheng MP, Sheppard DC, Nguyen D. Microbial Biofilms in Pulmonary and Critical Care Diseases. Annals of the American Thoracic Society. 2016; 13(9): 1615-1623. doi: 10.1513/AnnalsATS.201603-194FR

11. Mulcahy LR, Isabella VM, Lewis K. Pseudomonas aeruginosa biofilms in disease. Microbial Ecology.2014; 68(1): 1-12. doi: 10.1007/s00248-013-0297-x

12. Lebeaux D, Ghigo JM, Beloin C. Biofilm-related infections: bridging the gap between clinical management and fundamental aspects of recalcitrance toward antibiotics. Microbiology and Molecular Biology Reviews. 2014; 78(3): 510-543. doi: 10.1128/MMBR.00013-14

13. Tolker-Nielsen T. Pseudomonas aeruginosa biofilm infections: from molecular biofilm biology to new treatment possibilities. Journal of Pathology, Microbiology and Immunology. 2014; 138: 1-51. doi: 10.1111/apm.12335

14. Alhede M, Bjarnsholt T, Givskov M, Alhede M. Pseudomonas aeruginosa biofilms: mechanisms of immune evasion. Advances in applied microbiology. 2014; 86: 1-40. doi: 10.1016/B978-0-12-800262-9.00001-9

15. Miller JM, Binnicker MJ, Campbell S, Carroll KC, Chapin KC, Gilligan PH, et al. A Guide to Utilization of the Microbiology Laboratory for Diagnosis of Infectious Diseases: 2018 Update by the Infectious Diseases Society of America and the American Society for Microbiologya. Clinical Infectious Diseases: an official publication of the Infectious Diseases Society of America. 2018; 67(6): e1-e94. doi: 10.1093/cid/ciy381

16. Romanova lu M, Alekseeva, NV, Smirnova TA, Andreev AL, Didenko LV, Gintsburg AL. [Biofilms formation by different strains of Salmonella typhimurium in artificial systems]. Zhurnal Microbiologii, Epidemiologii $i$ Immunobiologii. 2006; 4: 38-42.

17. Deinhardt-Emmer S, Haupt KF, Garcia-Moreno M, Geraci J, Forstner C, Pletz M, Ehrhardt C, Löfler B. Staphylococcus aureus Pneumonia: Preceding Influenza Infection Paves the Way for Low-Virulent Strains. Toxins. 2019; 11(12): 734. doi: 10.3390/toxins11120734 
18. Al-Wrafy F, Brzozowska E, Górska S, Gamian A. Pathogenic factors of Pseudomonas aeruginosa - the role of biofilm in pathogenicity and as a target for phage therapy. Postepy Higieny i Medycyny Doswiadczalnej (online), 2016; 71(0): 78-91. doi: 10.5604/01.3001.0010.3792

19. Curran CS, Bolig T, Torabi-Parizi P. Mechanisms and Targeted Therapies for Pseudomonas aeruginosa Lung Infection. American Journal of Respiratory and Critical Care Medicine. 2018; 197(6): 708-727. doi: 10.1164/ rccm.201705-1043SO

20. Costerton JW. The Biofilm Primer (VIII) Vol 1. Berlin: Springer, 2007. 200 p.

21. Kreft J-U. Biofilms promote altruism. Microbiology. 2004; 150(8): 2751-2760. doi: 10.1099/mic.0.26829-0

22. Mehta P, Goyal S, Long T, Bassler BL, Wingreen NS. Information processing and signal integration in bacterial quorum sensing. Molecular Systems Biology. 2009; 5: 325. doi: 10.1038/msb.2009.79

23. Gostev VV, Sidorenko SV. Bacterial biofilms and infection. Journal of Infectology. 2010; 2(3). doi: 10.22625/20726732-2010-2-3-4-15

\section{УДК 579.262.085:579.861.2:579.862. 1:579.841.11:579.842.16:616.2-053.2 \\ ВИЗНАЧЕННЯ ЗДАТНОСТІ МІКРООРГАНІЗМІВ, ЯКІ ВИКЛИКАЮТЬ ЗАХВОРЮВАННЯ ОРГАНІВ ДИХАННЯ У ДІТЕЙ, ФОРМУВАТИ БІОПЛІВКИ У ЕКСПЕРИМЕНТІ in vitro \\ Ісаєва Г. О., Мішина М. М., Мозгова Ю. А., Гончарь М. О., Логвінова О. Л., Басюк М. А.}

Резюме. Метою дослідження було виявлення здатності мікроорганізмів, які викликають захворювання органів дихання у дітей, до біоплівкоутворення. Від пацієнтів було виділено 97 штамів мікроорганізмів, з них 44 штами S. aureus (від пацієнтів з пневмоніями - 13, від пацієнтів з іншими захворюваннями органів дихання - 31), 34 штами S. pneumoniae (від пацієнтів з пневмоніями - 27, від пацієнтів з іншими захворюваннями органів дихання - 7), 13 штамів K. pneumoniae (від пацієнтів з пневмоніями - 6, від пацієнтів з іншими захворюваннями органів дихання - 7), 6 штамів $P$. aeruginosa (від пацієнтів 3 пневмоніями - 5, від пацієнтів з іншими захворюваннями органів дихання - 1). Дослідження здатності мікроорганізмів до біоплівкоутворення визначали за допомогою визначення здатності штамів бактерій до адгезії на поверхні полістиролу в 96-ти лункових планшетів для імуноферментного аналізу. Визначення оптичної щільності проводилось за допомогою фотометра Multiskan при довжині хвилі 540 нм.

Оптична щільність первинних біоплівок, які формували Грампозитивні мікроорганізми була $1.33 \pm 0.24$ од.ощ., вторинних - 0.32 \pm 0.10 од.ощ. У пацієнтів з пневмонією ОЩ первинних біоплівок, що формували Грампозитивні мікроорганізми була $1.48 \pm 0.21$ од.ощ., а вторинних $-0.30 \pm 0.08$ од.ощ. У пацієнтів з іншими захворюваннями органів дихання оптична щільність первинних біоплівок, що формували Грампозитивні мікроорганізми була $1.18 \pm 0.15$ од.ощ., а вторинних $-0.35 \pm 0.12$ од.ощ.

Оптична щільність первинних біоплівок, які фрормували Грамнегативні мікроорганізми була $2.01 \pm 1.03$ од.ощ., а вторинних - 1.06 \pm 0.42 од.ощ. У пацієнтів з пневмонією оптична щільність пер-

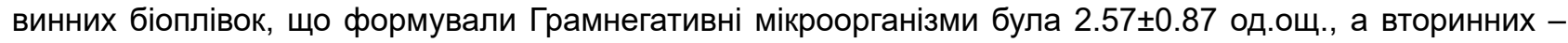
$1.21 \pm 0.50$ од. ощ. У пацієнтів з іншими захворюваннями органів дихання оптична щільність первинних біоплівок, що формували Грамнегативні мікроорганізми була $1.24 \pm 0.66$ од.ощ., а вторинних $0.84 \pm 0.11$ од. ощ.

Грамнегативні мікроорганізми формували більш щільні біоплівки у порівнянні з Грампозитивними мікроорганізмами. Штами P. aeruginosa, виділені від пацієнтів з пневмоніями, формували найбільш масивні, як первинні, так і вторинні біоплівки.

Ключові слова: біоплівки, діти, захворювання органів дихання, S. aureus, S. pneumoniae, K. pneumoniae, $P$. aeruginosa.

\section{УДК 579.262.085:579.861.2:579.862. 1:579.841.11:579.842.16:616.2-053.2 \\ ОПРЕДЕЛЕНИЕ СПОСОБНОСТИ МИКРООРГАНИЗМОВ, КОТОРЫЕ ВЫЗЫВАЮТ ЗАБОЛЕВАНИЯ ОРГАНОВ ДЫХАНИЯ У ДЕТЕЙ, ФОРМИРОВАТЬ БИОПЛЕНКИ В ЭКСПЕРИМЕНТЕ in vitro \\ Исаева А. О., Мишина М. М., Мозговая Ю. А., Гончарь М. А., Логвинова О. Л., Басюк М. А.}

Резюме. Целью исследования было определение способности микроорганизмов, которые вызывают заболевания органов дыхания у детей, формировать биопленки. От пациентов было выделено 97 штаммов микроорганизмов, из них 44 штамма S. aureus (от пациентов с пневмониями - 13, от пациентов с другими заболеваниями органов дыхания - 31), 34 штамма S. pneumoniae (от пациентов с пневмониями - 27, от пациентов с другими заболеваниями органов дыхания - 7), 13 штаммов 
K. pneumoniae (от пациентов с пневмониями - 6, от пациентов с другими заболеваниями органов дыхания - 7), 6 штаммов $P$. aeruginosa (от пациентов с пневмониями - 5, от пациентов с другими заболеваниями органов дыхания - 1). Исследование способности микроорганизмов формировать биопленки определяли с помощью способности штаммов к адгезии на поверхности полистирола в 96-луночных планшетах. Определение оптической плотности проводили с помощью фотометра Multiskan при длине волны 540 нм.

Оптическая плотность первичных биопленок, которые формировали Грамположительные микро-

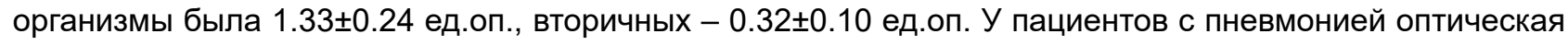
плотность первичных биопленок, которые формировали Грамположительные микроорганизмы была $1.48 \pm 0.21$ ед.оп., а вторичных - 0.30ะ0.08 ед.оп. У пациентов с другими заболеваниями органов дыхания оптическая плотность первичных биопленок, которые формировали Грамположительные микроорганизмы была $1.18 \pm 0.15$ ед.оп., а вторичных $-0.35 \pm 0.12$ ед.оп.

Оптическая плотность первичных биопленок, которые формировали Грамотрицательные микроор-

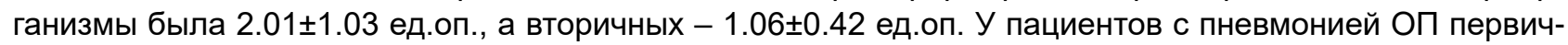
ных биопленок, которые формировали Грамотрицательные микроорганизмы была $2.57 \pm 0.87$ ед.оп., а

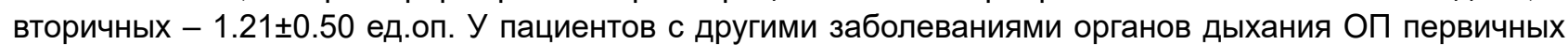
биопленок, которые формировали Грамотрицательные микроорганизмы была $1.24 \pm 0.66$ ед.оп., а вторичных - 0.84 \pm 0.11 ед.оп.

Грамотрицательные микроорганизмы формировали более плотные биопленки по сравнению с Грамположительными. Штаммы $P$. aeruginosa, выделенные от пациентов с пневмониями, формировали более массивные как первичные, так и вторичные биопленки.

Ключевые слова: биопленки, дети, заболевания органов дыхания, S. aureus, S. pneumoniae, K. pneumoniae, $P$. aeruginosa.

The authors of this study confirm that the research and publication of the results were not associated with any conflicts regarding commercial or financial relations, relations with organizations and/or individuals who may have been related to the study, and interrelations of coauthors of the article. 